\title{
Eu sou um erro
}

Jan Fabre

Monólogo para um fumante inveterado

(o texto é falado tossindo)

Eu sou um erro

Porque eu não pertenço a nenhuma raça

Eu sou um erro

Porque eu sou um movimento solitário

Eu sou um erro

Porque eu ainda sou curioso

Eu sou um erro

Porque eu sou meu próprio inimigo

Eu sou um erro

Porque eu não sou doente

Eu sou um erro

Porque eu não tenho medo da morte

Eu sou um erro

Porque eu não tenho nenhuma ligação com a

Sociedade contemporânea

(ele acende um cigarro)

Eu sou um erro

Porque eu sou uma colméia

Eu sou um erro

Porque eu detesto a moda

Eu sou um erro

Porque eu sou alienado

Eu sou um erro

Porque eu repito tudo
Eu sou um erro

Porque eu não acredito nas informações

Eu sou um erro

Porque eu sou mau ator

Eu sou um erro

Porque eu quero fazer o que não sou capaz

Eu sou um erro

(acende um cigarro)

Eu sou um erro

Porque eu falho em tudo

Eu sou um erro

Porque eu sou orgulhoso

Eu sou um erro

Porque eu sou um grandiloqüente grotesco

Eu sou um erro

Porque eu tenho uma angústia nobre

Eu sou um erro

Porque eu tenho útero

Eu sou um erro

Porque a vida íntima dos outros me entedia

Eu sou um erro

Porque eu sou um anão idiota

(acende um cigarro)

Eu sou um erro

Porque eu não gosto de falar de mim

Eu sou um erro

Porque eu gosto da pobreza

Texto publicado em Jan Fabre, "Je suis une erreur" (texto completo), in L'Histoire des larmes et autres pièces, versão francesa de Olivier Taymans, Paris, L’Arche, 2005, p. 195-207. Tradução de Sílvia Fernandes. 
Eu sou um erro

Porque eu não acredito na erudição

Eu sou um erro

Porque eu sou um animal perigoso

Eu sou um erro

Porque eu sou uma possibilidade

Eu sou um erro

Porque eu sou um desterrado

Eu sou um erro

Porque eu não tenho vergonha

(acende um cigarro)

Eu sou um erro

Porque eu desconfio do sol

Eu sou um erro

Porque eu destruo meu trabalho

Eu sou um erro

Porque eu sou muito nervoso

Eu sou um erro

Porque eu sou insensível

Eu sou um erro

Porque eu sou vadio

Eu sou um erro

Porque eu não conheço a ternura

Eu sou um erro

Porque eu não sou um homem

Eu sou um erro

Porque eu sou um deus

Eu sou um erro

Porque a insônia me faz viver numa tempestade de sonhos

Vagas de pesadelos

me afogam

E eu adoro isso.

Eu já imaginei, vivi e criei

tudo, eu disse tudo

E eu nunca

consegui

analisá-los

Eu tenho um sonho recorrente

Que me acompanha sempre

como um amigo fiel

Eu me vejo

num mar de seres humanos

eles têm um corpo
E eu...

Eu sou um corpo

Eu sou um corpo repleto de calor

Que aquece como brasa

Que fuma e que conspira

(ele acende um cigarro)

$\mathrm{O}$ cigarro é um prazer

para os sentidos

para o olho

para o olfato

e para o toque

Eu sou um erro

Porque eu sempre sacrifiquei

meu amor

passional

sublime

por um outro

amor passional sublime

Estou mentindo?

Isso não passava de um desejo?

Eu não podia mais distinguir

a verdade do fingimento

Foi isso que sempre me manteve vivo

Até agora

Eu sobrevivi

(ele acende um cigarro)

É um prazer contemplar o cigarro

Entre meus dedos

Sentir o filtro

entre meus lábios

Sentir a nicotina

em meus pulmões

Ver o movimento

das volutas de fumaça

Eu sou um erro

Porque eu desejo demais

É um desejo mais forte que a fome

E mais difícil de satisfazer

A anarquia do desejo

é inconciliável

com a vida

É mais radical que a vida

E por isso mais esmagadora

Só a morte 
pode salvá-la

acolhê-la

Quem acende um cigarro quer

celebrar sua alegria

ou esconder sua dor

Eu sou um erro

Porque eu moldo

Minha vida e minha obra

Ao meu gosto

DE MANEIRA ORGÂNICA

Sem me preocupar

com o que se deve fazer

ou com o que se deve dizer

Por isso eu não devo esperar

solidariedade...

Não devo contar com ela.

Por isso eu fumo só

(ele acende um cigarro)

O cigarro, parceiro

de todos os eventos

da vida

Eu sou um erro

Porque eu sou imortal

Às vezes é uma pena.

Morrer a tempo

pode ser bom

Para um artista.

Em muitos casos é

Uma correção histórica.

Vem no momento oportuno.

(ele atua com um cigarro aceso)

Eu gosto do movimento

Das cores

que se confundem

A chama pequena

que vacila

o reflexo

e a cintilação

a morte

do pequeno pavio de madeira

a cintilação

o carvão da madeira

a obscuridade

e o recomeço.
Eu sou um erro

Porque eu sou imortal

Às vezes é uma pena.

Seria preciso que eu sucumbisse

e o mundo exterior também.

(ele acende um cigarro)

Mais um cigarrinho

Um amigo fiel

nos dias difíceis

e nos dias melhores.

Eu me lembro...

de um artigo no New York Times

uma ode

Elogiosa à minha obra

Eu me lembro

da última frase

"Esse brilhante artista belga é um gênio"

Muito lisonjeiro para ser verdade

Mas devo ser honesto

Isso me deu prazer

Eu comecei a rir bem alto

porque eu dizia a mim mesmo...

que um artigo assim

não deixaria de causar

muita inveja e ciúme em meu país.

Eu deveria ter morrido naquela hora

naquele lugar

Mas infelizmente isso não aconteceu

Porque eu sou imortal

Eu sou um erro

Porque tudo que eu digo

eu penso

eu não conheço o cinismo

A ironia é para os fracos

Eu sou alguém

que se dá conta...

de que é um aristocrata contemporâneo

arrogante

e desastrado

Eu sou um erro

Porque eu sou insensato

Eu fumo

Eu fumo muito

fumo demais 
dia e noite

Eu tenho um câncer

um câncer na garganta

os médicos dizem...

que eu vou morrer

E mesmo assim eu fumo

Muito

Demais

A razão, é preciso deixá-la

aos imbecis

Eu não conseguiria mais me olhar no espelho

se eu me deixasse intimidar

pelos médicos

Eu não saberia

como continuar

a viver

Nem como morrer

(ele acende um cigarro)

Eu sou fiel

ao prazer

que tenta me matar. 